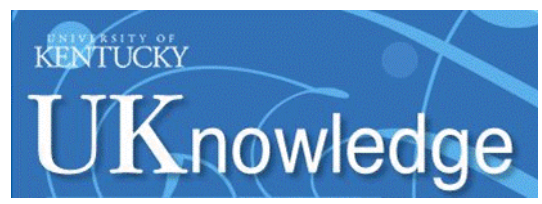

University of Kentucky

UKnowledge

6-2019

\title{
Crystal Structure of Zymonic Acid and a Redetermination of Its Precursor, Pyruvic Acid
}

\author{
Dominik Heger \\ University of Kentucky, hegerd@uky.edu
}

Alexis J. Eugene

University of Kentucky, alexis.eugene@uky.edu

Sean R. Parkin

University of Kentucky, s.parkin@uky.edu

Marcelo I. Guzman

University of Kentucky, marcelo.guzman@uky.edu

Follow this and additional works at: https://uknowledge.uky.edu/chemistry_facpub

Part of the Diagnosis Commons, Environmental Chemistry Commons, Food Chemistry Commons, Investigative Techniques Commons, Laboratory and Basic Science Research Commons, Organic Chemicals Commons, Organic Chemistry Commons, and the Physical Chemistry Commons

Right click to open a feedback form in a new tab to let us know how this document benefits you.

\section{Repository Citation}

Heger, Dominik; Eugene, Alexis J.; Parkin, Sean R.; and Guzman, Marcelo I., "Crystal Structure of Zymonic Acid and a Redetermination of Its Precursor, Pyruvic Acid" (2019). Chemistry Faculty Publications. 147. https://uknowledge.uky.edu/chemistry_facpub/147

This Article is brought to you for free and open access by the Chemistry at UKnowledge. It has been accepted for inclusion in Chemistry Faculty Publications by an authorized administrator of UKnowledge. For more information, please contact UKnowledge@lsv.uky.edu. 


\section{Crystal Structure of Zymonic Acid and a Redetermination of Its Precursor, Pyruvic}

Acid

\section{Digital Object Identifier (DOI)}

https://doi.org/10.1107/S2056989019007072

\section{Notes/Citation Information}

Published in Acta Crystallographica Section E: Crystallographic Communications, v. 75, part 6, p. 858-862.

This is an open-access article distributed under the terms of the Creative Commons Attribution (CC-BY) Licence, which permits unrestricted use, distribution, and reproduction in any medium, provided the original authors and source are cited. 


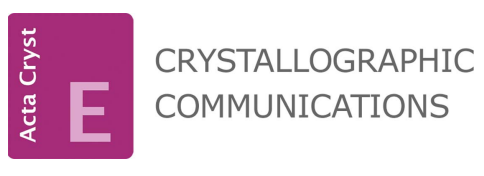

ISSN 2056-9890

Received 15 April 2019

Accepted 15 May 2019

Edited by W. T. A. Harrison, University of Aberdeen, Scotland

Keywords: crystal structure; hydrogen bonding; low temperature; zymonic; pyruvic.

CCDC references: $1916323 ; 1916322$

Supporting information: this article has supporting information at journals.iucr.org/e

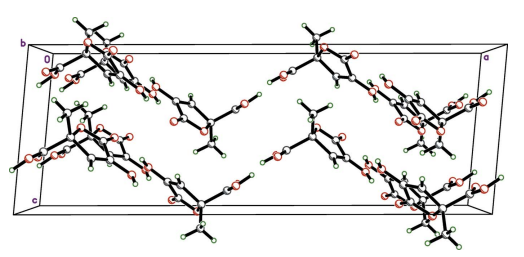

OPEN $\odot$ ACCESS

\section{Crystal structure of zymonic acid and a redetermination of its precursor, pyruvic acid}

\author{
Dominik Heger, ${ }^{\mathrm{a}, \mathrm{b} *}$ Alexis J. Eugene, ${ }^{\mathrm{a}}$ Sean R. Parkin ${ }^{\mathrm{a} *}$ and Marcelo I. Guzman ${ }^{\mathrm{a} *}$ \\ a'Department of Chemistry, University of Kentucky, Lexington, Kentucky 40506, USA, and ${ }^{\mathbf{b}}$ Department of Chemistry, \\ Faculty of Science, Masaryk University, Kamenice 5, 62500 Brno, Czech Republic. ${ }^{*}$ Correspondence e-mail: \\ hegerd@chemi.muni.cz,s.parkin@uky.edu,marcelo.guzman@uky.edu
}

The structure of zymonic acid (systematic name: 4-hydroxy-2-methyl-5-oxo-2,5dihydrofuran-2-carboxylic acid), $\mathrm{C}_{6} \mathrm{H}_{6} \mathrm{O}_{5}$, which had previously eluded crystallographic determination, is presented here for the first time. It forms by intramolecular condensation of parapyruvic acid, which is the product of aldol condensation of pyruvic acid. A redetermination of the crystal structure of pyruvic acid (systematic name: 2-oxopropanoic acid), $\mathrm{C}_{3} \mathrm{H}_{4} \mathrm{O}_{3}$, at low temperature $(90 \mathrm{~K})$ and with increased precision, is also presented [for the previous structure, see: Harata et al. (1977). Acta Cryst. B33, 210-212]. In zymonic acid, the hydroxylactone ring is close to planar (r.m.s. deviation = $0.0108 \AA$ ) and the dihedral angle between the ring and the plane formed by the bonds of the methyl and carboxylic acid carbon atoms to the ring is $88.68(7)^{\circ}$. The torsion angle of the carboxylic acid group relative to the ring is $12.04(16)^{\circ}$. The pyruvic acid molecule is almost planar, having a dihedral angle between the carboxylic acid and methyl-ketone groups of $3.95(6)^{\circ}$. Intermolecular interactions in both crystal structures are dominated by hydrogen bonding. The common $R_{2}^{2}(8)$ hydrogen-bonding motif links carboxylic acid groups on adjacent molecules in both structures. In zymonic acid, this results in dimers about a crystallographic twofold of space group $C 2 / c$, which forces the carboxylic acid group to be disordered exactly 50:50, which scrambles the carbonyl and hydroxyl groups and gives an apparent equalization of the $\mathrm{C}-\mathrm{O}$ bond lengths [1.2568 (16) and $1.2602(16) \AA]$. The other hydrogen bonds in zymonic acid $(\mathrm{O}-\mathrm{H} \cdots \mathrm{O}$ and weak $\mathrm{C}-\mathrm{H} \cdots \mathrm{O})$, link molecules across a $2_{1}$-screw axis, and generate an $R_{2}^{2}(9)$ motif. These hydrogen-bonding interactions propagate to form extended pleated sheets in the $a b$ plane. Stacking of these zigzag sheets along $c$ involves only van der Waals contacts. In pyruvic acid, inversion-related molecules are linked into $R_{2}^{2}(8)$ dimers, with van der Waals interactions between dimers as the only other intermolecular contacts.

\section{Chemical context}

The Human Metabolome Database (Wishart et al., 2007, 2009, 2013, 2018) lists the compound 4-hydroxy-2-methyl-5-oxofuran-2-carboxylic acid $\left(\mathrm{C}_{6} \mathrm{H}_{6} \mathrm{O}_{5}\right)$, commonly named zymonic acid, with the metabocard HMDB0031210. Zymonic acid is used as a flavor constituent for confectionery and tobacco products (Yannai, 2004). The generation of zymonic acid can proceed by condensation of parapyruvic acid, which itself forms by aldol condensation of pyruvic acid (IUPAC name 2oxopropanoic acid, $\mathrm{C}_{3} \mathrm{H}_{4} \mathrm{O}_{3}$; Bloomer et al., 1970). Therefore, zymonic acid is directly derived from pyruvic acid, and is thus related to the compounds present in the tricarboxylic acid (Krebs) cycle (Nelson \& Cox, 2004) and its reductive version (Guzman, 2011; Guzman \& Martin, 2008; Zhou \& Guzman, 2016). As an intermediate in central metabolism, zymonic acid 
is produced in the cytoplasm at very low concentration, from where it can be excreted to the extracellular region.

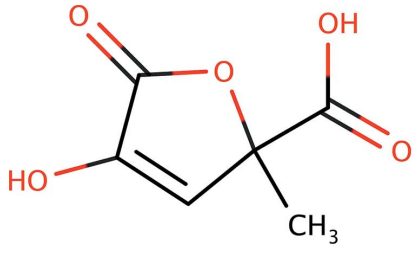

zymonic acid<smiles>CC(=O)C(=O)O</smiles>

pyruvic acid
The electron-impact mass spectrum (MS) and electrospray ionization fragmentation of zymonic acid following gas and liquid chromatography, respectively, have been reported (Allen et al., 2015, 2016). The use of ${ }^{13} \mathrm{C}$-zymonic acid has enabled mapping of $\mathrm{pH}$ changes, independently of concentration, in mammalian organs and tumors via hyperpolarized magnetic resonance (Düwel et al., 2017). Thus, zymonic acid is a non-invasive extracellular imaging sensor to localize and quantify $\mathrm{pH}$ in vivo (Düwel et al., 2017; Hundshammer et al., 2017), with many possible applications in medical diagnosis (Schilling et al., 2016). As part of the process resulting in the aforementioned invention, the detailed ${ }^{1} \mathrm{H}$ and ${ }^{13} \mathrm{C}$ NMR spectra of pure zymonic acid have been reported (Hundshammer et al., 2017). Herein, we contribute new information to characterize zymonic acid by reporting for the first time its crystal structure, along with a low-temperature redetermination of pyruvic acid.

\section{Structural commentary}

Aside from the effects on the geometry of the carboxylic acid group in zymonic acid that stem from disorder about the twofold axis (see below), there are no unusual bond lengths or angles in either compound.

In zymonic acid (Fig. 1), the hydroxylactone ring is essentially planar (r.m.s. deviation $=0.0108 \AA$ ), with the largest deviation from planarity $[0.0171(8) \AA]$ for the ring oxygen atom, O3. The plane defined by the ring carbon atom $\mathrm{C} 4$, the methyl carbon atom $\mathrm{C} 6$, and the carboxylic acid carbon atom

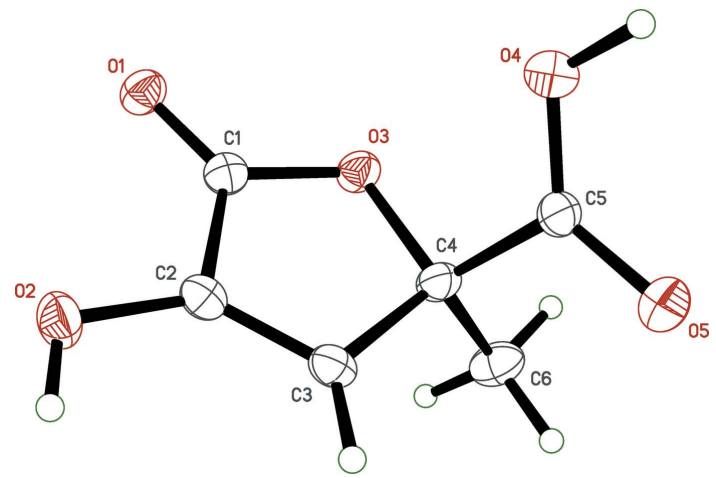

Figure 1

The molecular structure of zymonic acid, with displacement ellipsoids drawn at the $50 \%$ probability level.
Table 1

Hydrogen-bond geometry $\left(\AA,^{\circ}\right)$ for zymonic acid.

\begin{tabular}{lllll}
\hline$D-\mathrm{H} \cdots A$ & $D-\mathrm{H}$ & $\mathrm{H} \cdots A$ & $D \cdots A$ & $D-\mathrm{H} \cdots A$ \\
\hline $\mathrm{O} 2-\mathrm{H} 2 \cdots \mathrm{O} 1^{\mathrm{i}}$ & 0.84 & 1.96 & $2.7103(14)$ & 148 \\
$\mathrm{C} 3-\mathrm{H} 3 \cdots 2^{\mathrm{i}}$ & 0.95 & 2.48 & $3.0720(16)$ & 120 \\
$\mathrm{O} 4-\mathrm{H} 4 O \cdots \mathrm{O} 4^{\mathrm{ii}}$ & 1.09 & 1.52 & $2.607(2)$ & 176 \\
$\mathrm{O} 5-\mathrm{H} 5 O \cdots 5^{\mathrm{ii}}$ & 0.99 & 1.63 & $2.624(2)$ & 179 \\
\hline
\end{tabular}

Symmetry codes: (i) $-x+\frac{3}{2}, y+\frac{1}{2},-z+\frac{3}{2}$; (ii) $-x+1, y,-z+\frac{3}{2}$.

C5, is almost perpendicular to the mean plane of the ring atoms [dihedral angle $=88.68(7)^{\circ}$ ]. Lastly, the orientation of the carboxylic acid group relative to the ring, as defined by the torsion angle $\mathrm{O} 4-\mathrm{C} 5-\mathrm{C} 4-\mathrm{O} 3$, is $12.04(16)^{\circ}$. For the carboxylic acid group, disorder about the crystallographic twofold axis effectively averages the $\mathrm{C}=\mathrm{O}$ double and $\mathrm{C}-\mathrm{O}$ single bonds, rendering them equivalent [the $\mathrm{C} 5-\mathrm{O} 4$ and $\mathrm{C} 5-\mathrm{O} 5$ distances are 1.2568 (16) and 1.2602 (16) $\AA$, respectively], and requires modeling of half-occupancy hydrogens ( $\mathrm{H} 4 \mathrm{O}$ and $\mathrm{H} 5 \mathrm{O}$ ) on each.

In spite of increased precision resulting from much lower temperature $(90 \mathrm{~K}$ versus $266 \mathrm{~K}$ ) and data collection on modern equipment, the redetermined structure of pyruvic acid (Fig. 2) is largely unchanged from that reported by Harata et al. (1977). For example, the dihedral angle between the planes defined by atoms $\mathrm{C} 1 / \mathrm{C} 2 / \mathrm{C} 3 / \mathrm{O} 3$ and $\mathrm{C} 1 / \mathrm{C} 2 / \mathrm{O} 1 / \mathrm{O} 2$ is $3.95(6)^{\circ}$ at 90.00 (2) $\mathrm{K}$ versus $3.5^{\circ}$ at 266 (1) $\mathrm{K}$.

\section{Supramolecular features}

The main intermolecular interactions in the crystals of both zymonic and pyruvic acids are hydrogen bonds. In zymonic acid, the carboxylic acid groups of adjacent molecules are related by a crystallographic twofold axis to form hydrogen bonds $\left[\mathrm{O} 4-\mathrm{H} 4 \mathrm{O} \cdots \mathrm{O} 4^{\mathrm{ii}}\right.$ and $\mathrm{O} 5-\mathrm{H} 5 \mathrm{O} \cdots \mathrm{O} 5^{\mathrm{ii}}$; symmetry code: (ii) $1-x, y, \frac{3}{2}-z$ ] giving $R_{2}^{2}(8)$ dimer motifs (Table 1 ). This common supramolecular construct in carboxylic acids usually occurs between inversion-related or symmetry-independent molecules. Here, the orientation of the dimer relative to the crystallographic twofold axis forces the average struc-

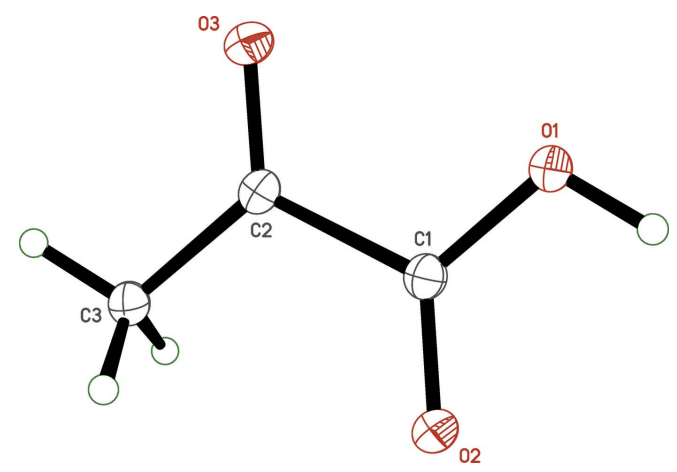

Figure 2

The molecular structure of pyruvic acid, with displacement ellipsoids drawn at the $50 \%$ probability level. 


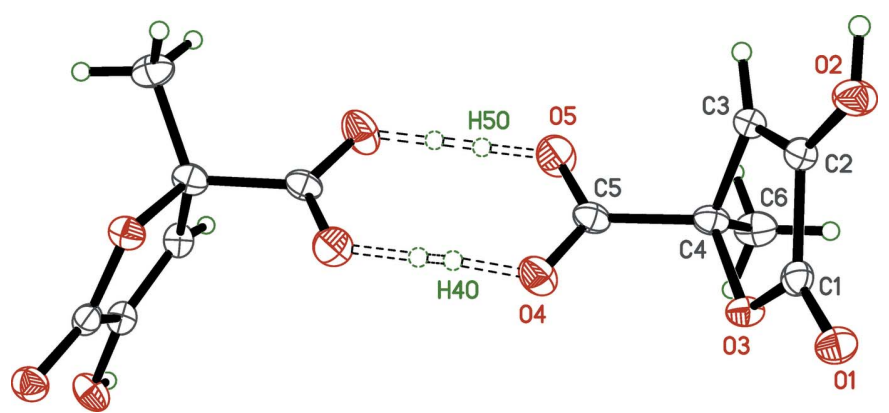

Figure 3

The $R_{2}^{2}(8)$ dimer of zymonic acid. Unlabeled atoms are related to their labeled counterparts by a crystallographic twofold axis $\left(1-x, y, \frac{3}{2}-z\right)$. This uncommon symmetry [for an $R_{2}^{2}(8)$ dimer] forces the $\mathrm{O}-\mathrm{H} \cdots \mathrm{O}$ hydrogen bonds involved to be 50:50 disordered about the twofold axis.

ture to be statistically disordered (Fig. 3). Another pair of hydrogen bonds $\left[\mathrm{O} 2-\mathrm{H} 2 \cdots \mathrm{O} 1^{\mathrm{i}}\right.$ and $\mathrm{C} 3-\mathrm{H} 3 \cdots \mathrm{O} 2^{\mathrm{i}}$; symmetry code: (i) $\left.\frac{3}{2}-x, \frac{1}{2}+y, \frac{3}{2}-z\right]$, link molecules related by a $21_{1}$-screw axis, into $R_{2}^{2}(9)$ motifs (Fig. 4$)$. These hydrogenbonding interactions combine to form extended pleated sheets that propagate in the $a b$ plane (Fig. 5), which in turn, stack along the $c$-axis direction. In pyruvic acid, inversion-related molecules form the common $R_{2}^{2}(8)$ dimer motif (Fig. 6,

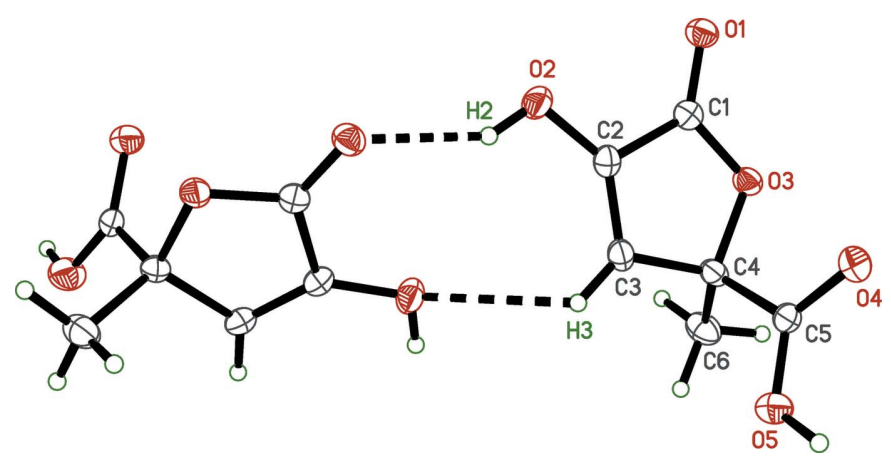

Figure 4

The $R_{2}^{2}(9)$ dimer of zymonic acid. Unlabeled atoms are related to their labeled counterparts by a crystallographic $2_{1}$-screw axis $\left(\frac{3}{2}-x, \frac{1}{2}+y, \frac{3}{2}-z\right)$. Disorder of the carboxylic acid $\mathrm{H}$ atoms is omitted to enhance clarity.

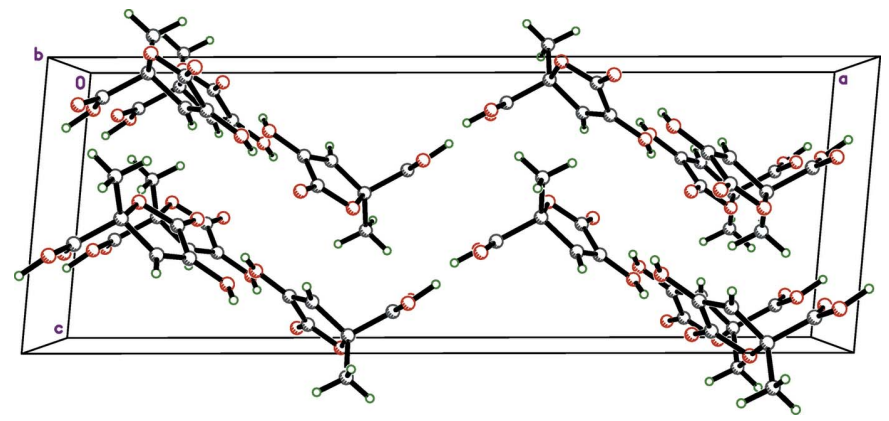

Figure 5

A packing plot of zymonic acid viewed down the $b$ axis, showing the stacking along $c$ of zigzag pleated assemblies of molecules. Disorder of the carboxylic acid hydrogen atoms is omitted to enhance clarity.
Table 2

Hydrogen-bond geometry $\left(\AA{ }^{\circ}\right)$ for pyruvic acid.

\begin{tabular}{lllll}
\hline$D-\mathrm{H} \cdots A$ & $D-\mathrm{H}$ & $\mathrm{H} \cdots A$ & $D \cdots A$ & $D-\mathrm{H} \cdots A$ \\
\hline $\mathrm{O} 1-\mathrm{H} 1 \cdots \mathrm{O} 2^{\mathrm{i}}$ & $0.913(14)$ & $1.742(14)$ & $2.6536(8)$ & $175.5(12)$ \\
\hline
\end{tabular}

Symmetry code: (i) $-x+1,-y+1,-z+1$.

Table 2). In accordance with the work of Harata et al. (1977), there are no other noteworthy intermolecular interactions.

\section{Database survey}

A search of the Cambridge Crystal Structure Database (Version 5.40, Nov. 2018; Groom et al., 2016) for zymonic acid gave no hits for searches on either 'zymonic' or on the structural formula. A search on the structural formula of pyruvic acid gave two hits. CSD entry PRUVAC (Harata et al., 1977) describes the pure compound at $266 \mathrm{~K}$, and is similar to the present pyruvic acid structure (after transformation to a common cell setting). CSD entry FAFGUR (Prohens et al., 2016) describes a co-crystal of pyruvic acid with the drug agomelatine. The CSD does contain structures for derivatives of both zymonic and pyruvic acids, but none of these have features that are especially relevant to the current work.

\section{Synthesis and crystallization}

Vacuum distillation of pyruvic acid (Sigma-Aldrich, 98.5\%) was used for purification (Eugene \& Guzman, 2017a,b). Freshly distilled pyruvic acid was crystallized in a closed vial in a freezer at $253 \mathrm{~K}$. The tail of this distillation, a viscous yellowish residue enriched in parapyruvic and zymonic acids, was isolated in a vial, and the headspace filled with $\mathrm{N}_{2}(\mathrm{~g})$ before sealing it with a cap. Crystals of zymonic acid were produced slowly from this isolated residue kept at $275 \mathrm{~K}$ inside a refrigerator. The easily identifiable transparent crystals of zymonic acid appear above the level of the viscous solution within two weeks. Pyruvic acid crystals are deliquescent in air, even at $263 \mathrm{~K}$ (Harata et al., 1977), so they had to be kept cold, with minimal exposure to ambient air. Thus, throughout all experimental stages from initial inspection through data collection, special techniques for crystal handling at low temperature (Parkin \& Hope, 1998) were employed.

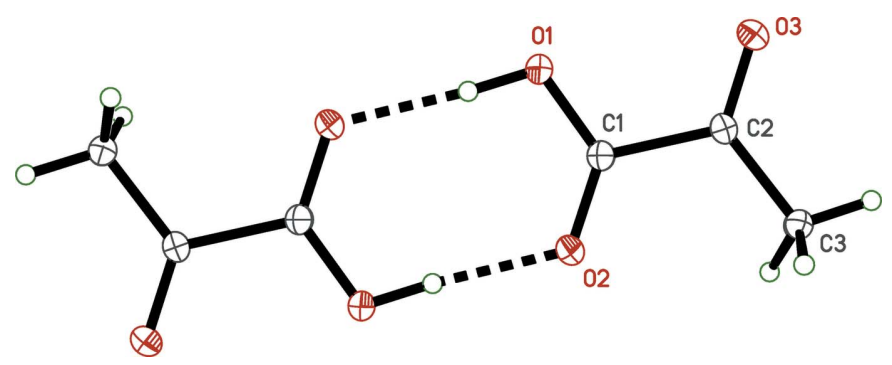

Figure 6

The $R_{2}^{2}(8)$ dimer of pyruvic acid. Unlabeled atoms are related to their labeled counterparts by crystallographic inversion symmetry $(1-x, 1-y$, $1-z)$. 
Table 3

Experimental details.

zymonic acid

$\mathrm{C}_{6} \mathrm{H}_{6} \mathrm{O}_{5}$
158.11
Monoclinic, $C 2 / c$
90
$24.145(3), 6.6523(7), 8.6201(7)$
$95.169(4)$
$1378.9(3)$
8
Mo $K \alpha$
0.14
$0.30 \times 0.25 \times 0.02$

Bruker D8 Venture dual source

Multi-scan (SADABS; Krause et al., 2015) $0.721,0.959$

$18595,1586,1392$

0.062

0.650

$0.037,0.100,1.09$

1586

104

$\mathrm{H}$ atoms treated by a mixture of independent and constrained refinement $0.36,-0.24$ pyruvic acid

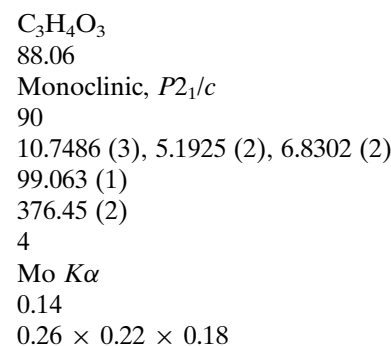

Bruker D8 Venture dual source

Multi-scan (SADABS; Krause et al., 2015)

$0.890,0.971$

$10479,1425,1242$

0.025

0.796

$0.031,0.082,1.08$

1425

60

$\mathrm{H}$ atoms treated by a mixture of independent and constrained refinement $0.40,-0.21$

$\Delta \rho_{\max }, \Delta \rho_{\min }\left(\mathrm{e} \AA^{-3}\right)$

Computer programs: APEX3 (Bruker, 2016), SHELXT (Sheldrick, 2015a), SHELXL2018/3 (Sheldrick, 2015b), XP in SHELXTL (Sheldrick, 2008), and CIFFIX (Parkin, 2013)

\section{Refinement}

Crystal data, data collection, and structure refinement details are summarized in Table 3. Non-disordered hydrogen atoms were found in difference Fourier maps. For pyruvic acid, the hydroxyl hydrogen-atom coordinates were refined freely, while methyl hydrogen $\mathrm{C}-\mathrm{H}$ distances used a riding model that allowed the $\mathrm{C}-\mathrm{H}$ distance to refine. For zymonic acid, riding models were used for all hydrogen atoms apart from those disordered about the twofold axis, which were modeled in accordance with the recommendations of Fábry (2018). $U_{\text {iso }}(\mathrm{H})$ parameters of non-disordered hydrogens were set to either $1.2 U_{\text {eq }}$ or $1.5 U_{\text {eq }}$ (for the methyl and hydroxyl groups, respectively) of the attached atom. To ensure stable refinement of disordered groups in the zymonic acid structure, constraints (SHELXL command EADP) were used to equalize displacement parameters of superimposed atoms.

\section{Funding information}

We are thankful for research funding from the National Science Foundation under NSF CAREER award CHE1255290 to MIG, and the MRI program, grants CHE-0319176 and CHE-1625732. An International Visiting Scholar grant from the College of Arts and Sciences at UK is gratefully acknowledged.

\section{References}

Allen, F., Greiner, R. \& Wishart, D. (2015). Metabolomics, 11, 98-110. Allen, F., Pon, A., Greiner, R. \& Wishart, D. (2016). Anal. Chem. 88, 7689-7697.

Bloomer, J. L., Gross, M. A., Kappler, F. E. \& Pandey, G. N. (1970). J. Chem. Soc. D, p. 1030a.

Bruker (2016). APEX3. Bruker AXS Inc., Madison, Wisconsin, USA.

Düwel, S., Hundshammer, C., Gersch, M., Feuerecker, B., Steiger, K., Buck, A., Walch, A., Haase, A., Glaser, S. J., Schwaiger, M. \& Schilling, F. (2017). Nat. Commun. 8, 15126.

Eugene, A. J. \& Guzman, M. I. (2017a). J. Phys. Chem. A, 121, 2924 2935.

Eugene, A. J. \& Guzman, M. I. (2017b). J. Phys. Chem. A, 121, 87418744.

Fábry, J. (2018). Acta Cryst. E74, 1344-1357.

Groom, C. R., Bruno, I. J., Lightfoot, M. P. \& Ward, S. C. (2016). Acta Cryst. B72, 171-179.

Guzman, M. I. (2011). Origins of Life: The Primal Self-Organization, edited by R. Egel, D.-H. Lankenau \& A. Y. Mulkidjanian, pp. 85105: Springer Berlin Heidelberg.

Guzman, M. I. \& Martin, S. T. (2008). Int. J. Astrobiology, 7, 271-278.

Harata, K., Sakabe, N. \& Tanaka, J. (1977). Acta Cryst. B33, 210-212.

Hundshammer, C., Düwel, S., Köcher, S. S., Gersch, M., Feuerecker, B., Scheurer, C., Haase, A., Glaser, S. J., Schwaiger, M. \& Schilling, F. (2017). ChemPhysChem, 18, 2422-2425.

Krause, L., Herbst-Irmer, R., Sheldrick, G. M. \& Stalke, D. (2015). J. Appl. Cryst. 48, 3-10.

Nelson, D. L. \& Cox, M. (2004). Lehninger Principles of Biochemistry, 4th ed. New York: W. H. Freeman.

Parkin, S. (2013). CIFFIX, https://xray.uky.edu/Resources/scripts/ ciffix 
Parkin, S. \& Hope, H. (1998). J. Appl. Cryst. 31, 945-953.

Prohens, R., Barbas, R., Portell, A., Font-Bardia, M., Alcobé, X. \& Puigjaner, C. (2016). Cryst. Growth Des. 16, 1063-1070.

Schilling, F., Glaser, S., Düwel, S. \& Gersch, M. (2016). pH-Biosensors Based on Compounds Produced From Pyruvic Acid For Magnetic Resonance Imaging and Spectroscopy and Their Uses. Google Patents.

Sheldrick, G. M. (2008). Acta Cryst. A64, 112-122.

Sheldrick, G. M. (2015a). Acta Cryst. A71, 3-8.

Sheldrick, G. M. (2015b). Acta Cryst. C71, 3-8.

Wishart, D. S., Feunang, Y. D., Marcu, A., Guo, A. C., Liang, K., Vázquez-Fresno, R., Sajed, T., Johnson, D., Li, C., Karu, N., Sayeeda, Z., Lo, E., Assempour, N., Berjanskii, M., Singhal, S., Arndt, D., Liang, Y., Badran, H., Grant, J., Serra-Cayuela, A., Liu, Y., Mandal, R., Neveu, V., Pon, A., Knox, C., Wilson, M., Manach, C. \& Scalbert, A. (2018). Nucleic Acids Res. 46, D608-D617.

Wishart, D. S., Jewison, T., Guo, A. C., Wilson, M., Knox, C., Liu, Y., Djoumbou, Y., Mandal, R., Aziat, F., Dong, E., Bouatra, S., Sinelnikov, I., Arndt, D., Xia, J., Liu, P., Yallou, F., Bjorndahl, T., Perez-Pineiro, R., Eisner, R., Allen, F., Neveu, V., Greiner, R. \& Scalbert, A. (2013). Nucleic Acids Res. 41, D801-D807.
Wishart, D. S., Knox, C., Guo, A. C., Eisner, R., Young, N., Gautam, B., Hau, D. D., Psychogios, N., Dong, E., Bouatra, S., Mandal, R., Sinelnikov, I., Xia, J., Jia, L., Cruz, J. A., Lim, E., Sobsey, C. A., Shrivastava, S., Huang, P., Liu, P., Fang, L., Peng, J., Fradette, R., Cheng, D., Tzur, D., Clements, M., Lewis, A., De Souza, A., Zuniga, A., Dawe, M., Xiong, Y., Clive, D., Greiner, R., Nazyrova, A., Shaykhutdinov, R., Li, L., Vogel, H. J. \& Forsythe, I. (2009). Nucleic Acids Res. 37, D603-D610.

Wishart, D. S., Tzur, D., Knox, C., Eisner, R., Guo, A. C., Young, N., Cheng, D., Jewell, K., Arndt, D., Sawhney, S., Fung, C., Nikolai, L., Lewis, M., Coutouly, M.-A., Forsythe, I., Tang, P., Shrivastava, S., Jeroncic, K., Stothard, P., Amegbey, G., Block, D., Hau, D. D., Wagner, J., Miniaci, J., Clements, M., Gebremedhin, M., Guo, N., Zhang, Y., Duggan, G. E., Macinnis, G. D., Weljie, A. M., Dowlatabadi, R., Bamforth, F., Clive, D., Greiner, R., Li, L., Marrie, T., Sykes, B. D., Vogel, H. J. \& Querengesser, L. (2007). Nucleic Acids Res. 35, D521-D526.

Yannai, S. (2004). Dictionary of food compounds with CD-ROM: Additives, flavors, and ingredients. Boca Raton: Chapman and Hall/ CRC.

Zhou, R. \& Guzman, M. I. (2016). J. Phys. Chem. C, 120, 7349-7357. 


\title{
supporting information
}

Acta Cryst. (2019). E75, 858-862 [https://doi.org/10.1107/S2056989019007072]

\section{Crystal structure of zymonic acid and a redetermination of its precursor, pyruvic acid}

\author{
Dominik Heger, Alexis J. Eugene, Sean R. Parkin and Marcelo I. Guzman \\ Computing details
}

For both structures, data collection: APEX3 (Bruker, 2016); cell refinement: APEX3 (Bruker, 2016); data reduction: APEX3 (Bruker, 2016); program(s) used to solve structure: SHELXT (Sheldrick, 2015a). Program(s) used to refine structure: SHELXL2018/3 (Sheldrick, 2015b) for zymonic; SHELXL2018 (Sheldrick, 2015b) for pyruvic. For both structures, molecular graphics: XP in SHELXTL (Sheldrick, 2008); software used to prepare material for publication: SHELXL (Sheldrick, 2008) and CIFFIX (Parkin, 2013).

4-Hydroxy-2-methyl-5-oxo-2,5-dihydrofuran-2-carboxylic acid (zymonic)

Crystal data

$\mathrm{C}_{6} \mathrm{H}_{6} \mathrm{O}_{5}$

$M_{r}=158.11$

Monoclinic, $C 2 / c$

$a=24.145(3) \AA$

$b=6.6523(7) \AA$

$c=8.6201(7) \AA$

$\beta=95.169(4)^{\circ}$

$V=1378.9(3) \AA^{3}$

$Z=8$

Data collection

Bruker D8 Venture dual source diffractometer

Radiation source: microsource

Detector resolution: 5.6 pixels $\mathrm{mm}^{-1}$

$\varphi$ and $\omega$ scans

Absorption correction: multi-scan

(SADABS; Krause et al., 2015)

$T_{\min }=0.721, T_{\max }=0.959$

Refinement

Refinement on $F^{2}$

Least-squares matrix: full

$R\left[F^{2}>2 \sigma\left(F^{2}\right)\right]=0.037$

$w R\left(F^{2}\right)=0.100$

$S=1.09$

1586 reflections

104 parameters

0 restraints
$F(000)=656$

$D_{\mathrm{x}}=1.523 \mathrm{Mg} \mathrm{m}^{-3}$

Mo $K \alpha$ radiation, $\lambda=0.71073 \AA$

Cell parameters from 9925 reflections

$\theta=3.2-27.5^{\circ}$

$\mu=0.14 \mathrm{~mm}^{-1}$

$T=90 \mathrm{~K}$

Thin plate, colourless

$0.30 \times 0.25 \times 0.02 \mathrm{~mm}$

18595 measured reflections

1586 independent reflections

1392 reflections with $I>2 \sigma(I)$

$R_{\text {int }}=0.062$

$\theta_{\max }=27.5^{\circ}, \theta_{\min }=3.2^{\circ}$

$h=-31 \rightarrow 31$

$k=-8 \rightarrow 8$

$l=-11 \rightarrow 10$

Primary atom site location: structure-invariant direct methods

Secondary atom site location: difference Fourier map

Hydrogen site location: mixed

$\mathrm{H}$ atoms treated by a mixture of independent and constrained refinement

$w=1 /\left[\sigma^{2}\left(F_{0}^{2}\right)+(0.0428 P)^{2}+1.4377 P\right]$

where $P=\left(F_{\mathrm{o}}^{2}+2 F_{\mathrm{c}}^{2}\right) / 3$ 
$(\Delta / \sigma)_{\max }=0.001$

$\Delta \rho_{\max }=0.36 \mathrm{e} \AA^{-3}$

$\Delta \rho_{\min }=-0.24 \mathrm{e} \AA^{-3}$
Extinction correction: SHELXL2018

(Sheldrick, 2015a),

$\mathrm{Fc}^{*}=\mathrm{kFc}\left[1+0.001 \mathrm{xFc}^{2} \lambda^{3} / \sin (2 \theta)\right]^{-1 / 4}$

Extinction coefficient: 0.0057 (13)

\section{Special details}

Experimental. The crystal was mounted using polyisobutene oil on the tip of a fine glass fibre, which was fastened in a copper mounting pin with electrical solder. It was placed directly into the cold gas stream of a liquid-nitrogen based cryostat (Hope, 1994; Parkin \& Hope, 1998).

Diffraction data were collected with the crystal at $90 \mathrm{~K}$, which is standard practice in this laboratory for the majority of flash-cooled crystals.

Geometry. All esds (except the esd in the dihedral angle between two 1.s. planes) are estimated using the full covariance matrix. The cell esds are taken into account individually in the estimation of esds in distances, angles and torsion angles; correlations between esds in cell parameters are only used when they are defined by crystal symmetry. An approximate (isotropic) treatment of cell esds is used for estimating esds involving l.s. planes.

Refinement. Refinement progress was checked using Platon (Spek, 2009) and by an R-tensor (Parkin, 2000). The final model was further checked with the IUCr utility checkCIF.

Fractional atomic coordinates and isotropic or equivalent isotropic displacement parameters $\left(\AA^{2}\right)$

\begin{tabular}{llllll}
\hline & $x$ & $y$ & $z$ & $U_{\text {iso }} / U_{\mathrm{eq}}$ & Occ. $(<1)$ \\
\hline $\mathrm{C} 1$ & $0.67036(5)$ & $0.40914(19)$ & $0.56905(14)$ & $0.0170(3)$ & \\
$\mathrm{O} 1$ & $0.68738(4)$ & $0.24154(14)$ & $0.54864(11)$ & $0.0209(2)$ & \\
$\mathrm{C} 2$ & $0.69378(5)$ & $0.5659(2)$ & $0.67706(14)$ & $0.0178(3)$ & \\
O2 & $0.74026(4)$ & $0.51656(15)$ & $0.76588(12)$ & $0.0240(3)$ & \\
$\mathrm{H} 2$ & 0.752557 & 0.618162 & 0.815574 & $0.036^{*}$ & \\
$\mathrm{C} 3$ & $0.66149(5)$ & $0.7275(2)$ & $0.66335(15)$ & $0.0182(3)$ & \\
$\mathrm{H} 3$ & 0.667502 & 0.849554 & 0.719574 & $0.022^{*}$ & \\
O3 & $0.62412(4)$ & $0.48283(13)$ & $0.48901(11)$ & $0.0188(2)$ & \\
C4 & $0.61371(5)$ & $0.68442(19)$ & $0.54353(15)$ & $0.0186(3)$ & \\
O4 & $0.54061(4)$ & $0.51162(15)$ & $0.66013(12)$ & $0.0249(3)$ & \\
H4O & 0.507244 & 0.517998 & 0.736346 & $0.109(14)^{*}$ & 0.5 \\
O5 & $0.54177(4)$ & $0.84824(16)$ & $0.66262(14)$ & $0.0303(3)$ & \\
H5O & 0.509866 & 0.849228 & 0.727610 & $0.109(14)^{*}$ & 0.5 \\
C5 & $0.56056(5)$ & $0.67919(19)$ & $0.62725(15)$ & $0.0188(3)$ & \\
C6 & $0.60945(7)$ & $0.8285(2)$ & $0.40645(17)$ & $0.0257(3)$ & \\
H6A & 0.644218 & 0.825746 & 0.355945 & $0.039^{*}$ & \\
H6B & 0.602833 & 0.964985 & 0.443442 & $0.039^{*}$ & \\
H6C & 0.578557 & 0.787894 & 0.331471 & $0.039^{*}$ & \\
\end{tabular}

Atomic displacement parameters $\left(\AA^{2}\right)$

\begin{tabular}{lllllll}
\hline & $U^{11}$ & $U^{22}$ & $U^{33}$ & $U^{12}$ & $U^{13}$ & $U^{23}$ \\
\hline C1 & $0.0184(6)$ & $0.0180(6)$ & $0.0151(6)$ & $-0.0007(5)$ & $0.0038(5)$ & $0.0010(5)$ \\
O1 & $0.0238(5)$ & $0.0173(5)$ & $0.0213(5)$ & $0.0015(4)$ & $0.0010(4)$ & $-0.0013(4)$ \\
C2 & $0.0165(6)$ & $0.0204(6)$ & $0.0165(6)$ & $-0.0023(5)$ & $0.0016(5)$ & $-0.0020(5)$ \\
O2 & $0.0186(5)$ & $0.0249(5)$ & $0.0274(5)$ & $0.0035(4)$ & $-0.0050(4)$ & $-0.0073(4)$ \\
C3 & $0.0168(6)$ & $0.0190(6)$ & $0.0190(6)$ & $-0.0032(5)$ & $0.0020(5)$ & $-0.0036(5)$ \\
O3 & $0.0213(5)$ & $0.0155(5)$ & $0.0192(5)$ & $0.0003(3)$ & $-0.0013(4)$ & $-0.0027(3)$ \\
C4 & $0.0205(6)$ & $0.0135(6)$ & $0.0212(6)$ & $-0.0007(5)$ & $-0.0012(5)$ & $-0.0018(5)$
\end{tabular}




\begin{tabular}{lllllll} 
O4 & $0.0225(5)$ & $0.0207(5)$ & $0.0314(6)$ & $-0.0031(4)$ & $0.0027(4)$ & $0.0013(4)$ \\
O5 & $0.0252(5)$ & $0.0209(5)$ & $0.0457(7)$ & $0.0027(4)$ & $0.0074(5)$ & $-0.0040(4)$ \\
C5 & $0.0165(6)$ & $0.0171(6)$ & $0.0217(6)$ & $0.0004(5)$ & $-0.0042(5)$ & $-0.0001(5)$ \\
C6 & $0.0351(8)$ & $0.0192(7)$ & $0.0223(7)$ & $-0.0013(6)$ & $-0.0008(6)$ & $0.0026(5)$ \\
\hline
\end{tabular}

Geometric parameters $\left(\AA,{ }^{o}\right)$

\begin{tabular}{|c|c|c|c|}
\hline $\mathrm{C} 1-\mathrm{O} 1$ & $1.2067(16)$ & $\mathrm{C} 4-\mathrm{C} 6$ & $1.5179(19)$ \\
\hline $\mathrm{C} 1-\mathrm{O} 3$ & $1.3505(15)$ & $\mathrm{C} 4-\mathrm{C} 5$ & $1.5282(19)$ \\
\hline $\mathrm{C} 1-\mathrm{C} 2$ & $1.4763(18)$ & $\mathrm{O} 4-\mathrm{C} 5$ & $1.2568(16)$ \\
\hline $\mathrm{C} 2-\mathrm{C} 3$ & $1.3268(18)$ & $\mathrm{O} 4-\mathrm{H} 4 \mathrm{O}$ & 1.0854 \\
\hline $\mathrm{C} 2-\mathrm{O} 2$ & $1.3411(16)$ & $\mathrm{O} 5-\mathrm{C} 5$ & $1.2602(16)$ \\
\hline $\mathrm{O} 2-\mathrm{H} 2$ & 0.8400 & $\mathrm{O} 5-\mathrm{H} 5 \mathrm{O}$ & 0.9926 \\
\hline $\mathrm{C} 3-\mathrm{C} 4$ & $1.5051(17)$ & $\mathrm{C} 6-\mathrm{H} 6 \mathrm{~A}$ & 0.9800 \\
\hline $\mathrm{C} 3-\mathrm{H} 3$ & 0.9500 & $\mathrm{C} 6-\mathrm{H} 6 \mathrm{~B}$ & 0.9800 \\
\hline $\mathrm{O} 3-\mathrm{C} 4$ & $1.4505(15)$ & $\mathrm{C} 6-\mathrm{H} 6 \mathrm{C}$ & 0.9800 \\
\hline $\mathrm{O} 1-\mathrm{C} 1-\mathrm{O} 3$ & $122.52(12)$ & $\mathrm{O} 3-\mathrm{C} 4-\mathrm{C} 5$ & $108.03(10)$ \\
\hline $\mathrm{O} 1-\mathrm{C} 1-\mathrm{C} 2$ & $128.95(12)$ & $\mathrm{C} 3-\mathrm{C} 4-\mathrm{C} 5$ & $107.73(11)$ \\
\hline $\mathrm{O} 3-\mathrm{C} 1-\mathrm{C} 2$ & $108.53(11)$ & $\mathrm{C} 6-\mathrm{C} 4-\mathrm{C} 5$ & $112.41(11)$ \\
\hline $\mathrm{C} 3-\mathrm{C} 2-\mathrm{O} 2$ & $134.75(12)$ & $\mathrm{C} 5-\mathrm{O} 4-\mathrm{H} 4 \mathrm{O}$ & 115.0 \\
\hline $\mathrm{C} 3-\mathrm{C} 2-\mathrm{C} 1$ & $109.12(11)$ & $\mathrm{C} 5-\mathrm{O} 5-\mathrm{H} 5 \mathrm{O}$ & 117.2 \\
\hline $\mathrm{O} 2-\mathrm{C} 2-\mathrm{C} 1$ & $116.12(11)$ & $\mathrm{O} 4-\mathrm{C} 5-\mathrm{O} 5$ & $125.69(13)$ \\
\hline $\mathrm{C} 2-\mathrm{O} 2-\mathrm{H} 2$ & 109.5 & $\mathrm{O} 4-\mathrm{C} 5-\mathrm{C} 4$ & $118.80(11)$ \\
\hline $\mathrm{C} 2-\mathrm{C} 3-\mathrm{C} 4$ & $108.35(11)$ & $\mathrm{O} 5-\mathrm{C} 5-\mathrm{C} 4$ & $115.45(11)$ \\
\hline $\mathrm{C} 2-\mathrm{C} 3-\mathrm{H} 3$ & 125.8 & $\mathrm{C} 4-\mathrm{C} 6-\mathrm{H} 6 \mathrm{~A}$ & 109.5 \\
\hline $\mathrm{C} 4-\mathrm{C} 3-\mathrm{H} 3$ & 125.8 & $\mathrm{C} 4-\mathrm{C} 6-\mathrm{H} 6 \mathrm{~B}$ & 109.5 \\
\hline $\mathrm{C} 1-\mathrm{O} 3-\mathrm{C} 4$ & $109.24(10)$ & $\mathrm{H} 6 \mathrm{~A}-\mathrm{C} 6-\mathrm{H} 6 \mathrm{~B}$ & 109.5 \\
\hline $\mathrm{O} 3-\mathrm{C} 4-\mathrm{C} 3$ & $104.7(1)$ & $\mathrm{C} 4-\mathrm{C} 6-\mathrm{H} 6 \mathrm{C}$ & 109.5 \\
\hline $\mathrm{O} 3-\mathrm{C} 4-\mathrm{C} 6$ & $109.47(11)$ & $\mathrm{H} 6 \mathrm{~A}-\mathrm{C} 6-\mathrm{H} 6 \mathrm{C}$ & 109.5 \\
\hline $\mathrm{C} 3-\mathrm{C} 4-\mathrm{C} 6$ & $114.07(11)$ & $\mathrm{H} 6 \mathrm{~B}-\mathrm{C} 6-\mathrm{H} 6 \mathrm{C}$ & 109.5 \\
\hline $\mathrm{O} 1-\mathrm{C} 1-\mathrm{C} 2-\mathrm{C} 3$ & $-179.25(13)$ & $\mathrm{C} 1-\mathrm{O} 3-\mathrm{C} 4-\mathrm{C} 5$ & $-112.19(11)$ \\
\hline $\mathrm{O} 3-\mathrm{C} 1-\mathrm{C} 2-\mathrm{C} 3$ & $1.17(15)$ & $\mathrm{C} 2-\mathrm{C} 3-\mathrm{C} 4-\mathrm{O} 3$ & $-1.69(14)$ \\
\hline $\mathrm{O} 1-\mathrm{C} 1-\mathrm{C} 2-\mathrm{O} 2$ & $-0.3(2)$ & $\mathrm{C} 2-\mathrm{C} 3-\mathrm{C} 4-\mathrm{C} 6$ & $-121.33(13)$ \\
\hline $\mathrm{O} 3-\mathrm{C} 1-\mathrm{C} 2-\mathrm{O} 2$ & $-179.92(10)$ & $\mathrm{C} 2-\mathrm{C} 3-\mathrm{C} 4-\mathrm{C} 5$ & $113.14(12)$ \\
\hline $\mathrm{O} 2-\mathrm{C} 2-\mathrm{C} 3-\mathrm{C} 4$ & $-178.23(14)$ & $\mathrm{O} 3-\mathrm{C} 4-\mathrm{C} 5-\mathrm{O} 4$ & $12.04(16)$ \\
\hline $\mathrm{C} 1-\mathrm{C} 2-\mathrm{C} 3-\mathrm{C} 4$ & $0.39(15)$ & $\mathrm{C} 3-\mathrm{C} 4-\mathrm{C} 5-\mathrm{O} 4$ & $-100.56(13)$ \\
\hline $\mathrm{O} 1-\mathrm{C} 1-\mathrm{O} 3-\mathrm{C} 4$ & $178.13(12)$ & $\mathrm{C} 6-\mathrm{C} 4-\mathrm{C} 5-\mathrm{O} 4$ & $132.92(13)$ \\
\hline $\mathrm{C} 2-\mathrm{C} 1-\mathrm{O} 3-\mathrm{C} 4$ & $-2.26(13)$ & $\mathrm{O} 3-\mathrm{C} 4-\mathrm{C} 5-\mathrm{O} 5$ & $-170.61(11)$ \\
\hline $\mathrm{C} 1-\mathrm{O} 3-\mathrm{C} 4-\mathrm{C} 3$ & $2.43(13)$ & $\mathrm{C} 3-\mathrm{C} 4-\mathrm{C} 5-\mathrm{O} 5$ & $76.79(14)$ \\
\hline $\mathrm{C} 1-\mathrm{O} 3-\mathrm{C} 4-\mathrm{C} 6$ & $125.11(12)$ & $\mathrm{C} 6-\mathrm{C} 4-\mathrm{C} 5-\mathrm{O} 5$ & $-49.72(16)$ \\
\hline
\end{tabular}

Hydrogen-bond geometry $\left(\AA,{ }^{\circ}\right)$

\begin{tabular}{lllll}
\hline$D-\mathrm{H} \cdots A$ & $D-\mathrm{H}$ & $\mathrm{H} \cdots A$ & $D \cdots A$ & $D-\mathrm{H} \cdots A$ \\
\hline $\mathrm{O} 2-\mathrm{H} 2 \cdots \mathrm{O} 1^{\mathrm{i}}$ & 0.84 & 1.96 & $2.7103(14)$ & 148 \\
$\mathrm{C} 3-\mathrm{H} 3 \cdots \mathrm{O} 2^{\mathrm{i}}$ & 0.95 & 2.48 & $3.0720(16)$ & 120
\end{tabular}




$\begin{array}{llllr}\mathrm{O} 4-\mathrm{H} 4 O \cdots \mathrm{O} 4^{\mathrm{ii}} & 1.09 & 1.52 & 2.607(2) & 176 \\ \mathrm{O} 5-\mathrm{H} 5 O \cdots{ }^{\mathrm{ii}} & 0.99 & 1.63 & 2.624(2) & 179\end{array}$

Symmetry codes: (i) $-x+3 / 2, y+1 / 2,-z+3 / 2$; (ii) $-x+1, y,-z+3 / 2$.

2-Oxopropanoic acid (pyruvic)

\section{Crystal data}

$\mathrm{C}_{3} \mathrm{H}_{4} \mathrm{O}_{3}$

$M_{r}=88.06$

Monoclinic, $P 2_{1} / c$

$a=10.7486(3) \AA$

$b=5.1925(2) \AA$

$c=6.8302(2) \AA$

$\beta=99.063(1)^{\circ}$

$V=376.45(2) \AA^{3}$

$Z=4$

\section{Data collection}

Bruker D8 Venture dual source diffractometer

Radiation source: microsource

Detector resolution: 5.6 pixels $\mathrm{mm}^{-1}$

$\varphi$ and $\omega$ scans

Absorption correction: multi-scan

(SADABS; Krause et al., 2015)

$T_{\min }=0.890, T_{\max }=0.971$

\section{Refinement}

Refinement on $F^{2}$

Least-squares matrix: full

$R\left[F^{2}>2 \sigma\left(F^{2}\right)\right]=0.031$

$w R\left(F^{2}\right)=0.082$

$S=1.08$

1425 reflections

60 parameters

0 restraints

Primary atom site location: structure-invariant direct methods
$F(000)=184$

$D_{\mathrm{x}}=1.554 \mathrm{Mg} \mathrm{m}^{-3}$

Mo $K \alpha$ radiation, $\lambda=0.71073 \AA$

Cell parameters from 6955 reflections

$\theta=3.8-34.3^{\circ}$

$\mu=0.14 \mathrm{~mm}^{-1}$

$T=90 \mathrm{~K}$

Well-facetted block, colourless

$0.26 \times 0.22 \times 0.18 \mathrm{~mm}$

10479 measured reflections

1425 independent reflections

1242 reflections with $I>2 \sigma(I)$

$R_{\text {int }}=0.025$

$\theta_{\max }=34.5^{\circ}, \theta_{\min }=3.8^{\circ}$

$h=-16 \rightarrow 16$

$k=-7 \rightarrow 8$

$l=-10 \rightarrow 10$

Secondary atom site location: difference Fourier map

Hydrogen site location: mixed

$\mathrm{H}$ atoms treated by a mixture of independent and constrained refinement

$w=1 /\left[\sigma^{2}\left(F_{0}^{2}\right)+(0.0299 P)^{2}+0.1264 P\right]$

where $P=\left(F_{\mathrm{o}}^{2}+2 F_{\mathrm{c}}^{2}\right) / 3$

$(\Delta / \sigma)_{\max }<0.001$

$\Delta \rho_{\max }=0.40 \mathrm{e} \AA^{-3}$

$\Delta \rho_{\min }=-0.21$ e $\AA^{-3}$

Special details

Experimental. The crystal was mounted using polyisobutene oil on the tip of a fine glass fibre, which was fastened in a copper mounting pin with electrical solder. It was placed directly into the cold gas stream of a liquid-nitrogen based cryostat (Parkin \& Hope, 1998).

Diffraction data were collected with the crystal at $90 \mathrm{~K}$, which is standard practice in this laboratory for the majority of flash-cooled crystals.

Geometry. All esds (except the esd in the dihedral angle between two 1.s. planes) are estimated using the full covariance matrix. The cell esds are taken into account individually in the estimation of esds in distances, angles and torsion angles; correlations between esds in cell parameters are only used when they are defined by crystal symmetry. An approximate (isotropic) treatment of cell esds is used for estimating esds involving l.s. planes.

Refinement. Refinement progress was checked using Platon (Spek, 2009) and by an $R$-tensor (Parkin, 2000). The final model was further checked with the IUCr utility checkCIF. 
Fractional atomic coordinates and isotropic or equivalent isotropic displacement parameters $\left(\AA^{2}\right)$

\begin{tabular}{lllll}
\hline & $x$ & $y$ & $z$ & $U_{\text {iso }} * / U_{\text {eq }}$ \\
\hline O1 & $0.41673(5)$ & $0.30370(12)$ & $0.30191(9)$ & $0.01968(14)$ \\
H1 & $0.4903(13)$ & $0.320(3)$ & $0.3883(19)$ & $0.030^{*}$ \\
C1 & $0.33963(6)$ & $0.48448(14)$ & $0.34005(11)$ & $0.01316(14)$ \\
O2 & $0.36317(5)$ & $0.65673(11)$ & $0.46175(8)$ & $0.01589(13)$ \\
C2 & $0.20853(6)$ & $0.46732(14)$ & $0.21028(10)$ & $0.01271(14)$ \\
C3 & $0.11464(7)$ & $0.65949(15)$ & $0.25725(11)$ & $0.01520(15)$ \\
H3A & $0.1499(3)$ & $0.8314(12)$ & $0.255(1)$ & $0.023^{*}$ \\
H3B & $0.0940(5)$ & $0.6245(9)$ & $0.388(1)$ & $0.023^{*}$ \\
H3C & $0.0389(6)$ & $0.6478(9)$ & $0.1594(9)$ & $0.023 *$ \\
O3 & $0.18824(5)$ & $0.30508(11)$ & $0.08250(9)$ & $0.01774(14)$ \\
\hline
\end{tabular}

Atomic displacement parameters $\left(\AA^{2}\right)$

\begin{tabular}{lllllll}
\hline & $U^{11}$ & $U^{22}$ & $U^{33}$ & $U^{12}$ & $U^{13}$ & $U^{23}$ \\
\hline O1 & $0.0132(2)$ & $0.0218(3)$ & $0.0222(3)$ & $0.0041(2)$ & $-0.0027(2)$ & $-0.0084(2)$ \\
C1 & $0.0121(3)$ & $0.0138(3)$ & $0.0136(3)$ & $-0.0002(2)$ & $0.0018(2)$ & $0.0003(2)$ \\
O2 & $0.0135(2)$ & $0.0155(3)$ & $0.0176(3)$ & $-0.00038(19)$ & $-0.00071(19)$ & $-0.0034(2)$ \\
C2 & $0.0119(3)$ & $0.0139(3)$ & $0.0121(3)$ & $-0.0011(2)$ & $0.0010(2)$ & $0.0009(2)$ \\
C3 & $0.0140(3)$ & $0.0163(3)$ & $0.0148(3)$ & $0.0023(2)$ & $0.0008(2)$ & $-0.0013(3)$ \\
O3 & $0.0167(3)$ & $0.0181(3)$ & $0.0173(3)$ & $-0.0002(2)$ & $-0.0008(2)$ & $-0.0049(2)$ \\
\hline
\end{tabular}

Geometric parameters $\left(\hat{A},{ }^{\circ}\right)$

\begin{tabular}{llll}
\hline $\mathrm{O} 1-\mathrm{C} 1$ & $1.3053(9)$ & $\mathrm{C} 2-\mathrm{C} 3$ & $1.4896(10)$ \\
$\mathrm{O} 1-\mathrm{H} 1$ & $0.913(14)$ & $\mathrm{C} 3-\mathrm{H} 3 \mathrm{~A}$ & $0.971(6)$ \\
$\mathrm{C} 1-\mathrm{O} 2$ & $1.2201(9)$ & $\mathrm{C} 3-\mathrm{H} 3 \mathrm{~B}$ & $0.971(6)$ \\
$\mathrm{C} 1-\mathrm{C} 2$ & $1.5446(10)$ & $\mathrm{C} 3-\mathrm{H} 3 \mathrm{C}$ & $0.971(6)$ \\
$\mathrm{C} 2-\mathrm{O} 3$ & $1.2079(9)$ & & \\
$\mathrm{C} 1-\mathrm{O} 1-\mathrm{H} 1$ & $108.4(8)$ & $\mathrm{C} 2-\mathrm{C} 3-\mathrm{H} 3 \mathrm{~A}$ & 109.5 \\
$\mathrm{O} 2-\mathrm{C} 1-\mathrm{O} 1$ & $126.37(7)$ & $\mathrm{C} 2-\mathrm{C} 3-\mathrm{H} 3 \mathrm{~B}$ & 109.5 \\
$\mathrm{O} 2-\mathrm{C} 1-\mathrm{C} 2$ & $120.38(6)$ & $\mathrm{H} 3 \mathrm{~A}-\mathrm{C} 3-\mathrm{H} 3 \mathrm{~B}$ & 109.5 \\
$\mathrm{O} 1-\mathrm{C} 1-\mathrm{C} 2$ & $113.24(6)$ & $\mathrm{C} 2-\mathrm{C} 3-\mathrm{H} 3 \mathrm{C}$ & 109.5 \\
$\mathrm{O} 3-\mathrm{C} 2-\mathrm{C} 3$ & $124.85(7)$ & $\mathrm{H} 3 \mathrm{~A}-\mathrm{C} 3-\mathrm{H} 3 \mathrm{C}$ & 109.5 \\
$\mathrm{O} 3-\mathrm{C} 2-\mathrm{C} 1$ & $119.96(7)$ & $\mathrm{H} 3 \mathrm{~B}-\mathrm{C} 3-\mathrm{H} 3 \mathrm{C}$ & \\
$\mathrm{C} 3-\mathrm{C} 2-\mathrm{C} 1$ & $115.19(6)$ & & $-4.59(10)$ \\
$\mathrm{O} 2-\mathrm{C} 1-\mathrm{C} 2-\mathrm{O} 3$ & $175.81(7)$ & $\mathrm{O} 2-\mathrm{C} 1-\mathrm{C} 2-\mathrm{C} 3$ & $176.26(6)$ \\
$\mathrm{O} 1-\mathrm{C} 1-\mathrm{C} 2-\mathrm{O} 3$ & $-3.34(10)$ & $\mathrm{O} 1-\mathrm{C} 1-\mathrm{C} 2-\mathrm{C} 3$ & \\
\hline
\end{tabular}

Hydrogen-bond geometry $\left(\AA,{ }^{\circ}\right)$

\begin{tabular}{lllll}
\hline$D-\mathrm{H} \cdots A$ & $D-\mathrm{H}$ & $\mathrm{H} \cdots A$ & $D \cdots A$ & $D-\mathrm{H} \cdots A$ \\
\hline $\mathrm{O} 1-\mathrm{H} 1 \cdots \mathrm{O} 2^{\mathrm{i}}$ & $0.913(14)$ & $1.742(14)$ & $2.6536(8)$ & $175.5(12)$ \\
\hline
\end{tabular}


Symmetry code: (i) $-x+1,-y+1,-z+1$. 